\title{
The potential of sugarcane bagasse polymer composite for sustainable of Stevia rebaudiana productivity under deficit irrigation
}

\author{
Grad, W.E. ${ }^{1}$, S.H. kandil' ${ }^{2}$, E. Kenawy ${ }^{3}$ and M.I. Massoud ${ }^{4 *}$ \\ ${ }^{1}$ Department of genetics and breeding, Agricultural research center, Alexandria, Egypt \\ ${ }^{2}$ Department of Materials Science, Institute of Graduate Studies and Research, Alexandria University \\ ${ }^{3}$ Department of Chemistry, Polymer Research Group, Faculty of Science, Tanta University, Egypt \\ ${ }^{4}$ Sugar Crops Research Institute, Agriculture Research Center, Alexandria, Egypt
}

\begin{abstract}
Recycling of ligno-cellulosic residues and economically viable crops production with improved water use efficiency is imperative to secure high-quality sustainable food production and implement the environmental sustainability. Therefore, the objective of this work was to evaluate superabsorbent sugarcane bagasse polymer composite (SBP) on Stevia rebaudiana quality and production under deficit irrigation. The experiment was conducted at Sabahia Agricultural Research Station, Alexandria, Egypt during two seasons 2017/2018 and $2018 / 2019$ under the greenhouse conditions. Three SBP treatments $(0.0,2.0$ and $4.0 \mathrm{~g} / 5 \mathrm{~kg}$ of soils) using three irrigation levels $(100 \%, 70 \%$ and $50 \%$ of field capacity) were applied. Data revealed that the soil amendment with SBP enhanced and gave the highest values of stevia growth parameters, chlorophyll, total soluble carbohydrate and steviol glycoside (SVglys) under both irrigation systems in both seasons. The SBP at dosage 2 and $4 \%$ levels into the soil led to an increase of dry leaves yield by 1.5 and 1.32 fold, respectively compared to yield in untreated soil under $70 \%$ field capacity. Calculated SVglys and determined by IR was high in soil amendment with $2.0 \%$ SBP $(15.60 \%)$ under $100 \%$ irrigation levels and nearly closed in $70 \%$ irrigation level (15.02\%). SBP application under deficit irrigation conditions increased of amount WUE and showed improvement in peroxidase isozyme system that can be used as a biomarker for characterizing drought stress tolerance. Hence, it could be recommended that SBP can be used to enhance the stevia productivity and enabled the survival of stevia plant under deficit irrigation conditions.
\end{abstract}

Keywords: Polymer; Composite; Peroxidase Isozyme; Steviol Glycoside

\section{Introduction}

There is considerable interest of recycling and utilization of organic agricultural wastes to maximize their-use efficiencies with minimizes the environmental pollution and economic profitability. These organic agricultural wastes are widely available,

\footnotetext{
*Corresponding author: Mona I. Massoud, Email: mona_massoud@hotmail.com Received: February 10, 2021;

Accepted: March 20, 2021;

Published: April 1, 2021.
}

renewable and can be converted into useful resources through their use as an environmentally friendly super absorbent organic composite to improve nutrient status of soils, and hence conserve the environment and enhance food security. According to El Haggar and El Gowini, (2005), sugarcane (Saccharum officinarum) bagasse is considered the main by-products and represents nearly $30 \%$ of the sugar cane industry. It is available in large quantities in the factories but still largely under-utilized, 
it is used as fuel in Egyptian sugar mills or as fiber in fiberboard and paper manufacturing. Production natural super absorbent polymers fertilizer from lignocellulosic of sugarcane bagasse leads to a decrease the irrigation rate and nutrient percolation with increase in the yield under normal irrigation and water stress condition, and hence is more safe than chemical fertilizers, (Sarvas et al., 2007, Rafiei and Nourmohammadi, 2013). The application of SAB composed as polyelectrolyte gels in agriculture increases irrigation and soil nutritional gaps by retaining water storage capacity, enhances water quality and reduces irrigation costs in arid and semi-arid soils that can be absorbed and thus saves costs and energy. The stevia rebaudiana herb is promising renewable medicinal plants as new natural sweetener source or as food additive in the food as well as, its medicinal benefit for diabetic and obese persons. Besides its sweetening properties, it showed antibacterial, antiseptic, anti-inflammatory, anti-fertility, hypotensive, diuretic and cardio tonic properties, (Ghaheri et al., 2018). Quality and productivity of the stevia depends on the concentration of steviol glycosides in the leaves that are 200300 times sweeter than sugar and effect by environmental conditions agronomical practices and nutritional factors, (Pal et al., 2015 and Ghaheri et al., 2018).

The lack of water is the most effect on agronomic characters and crop productivity in arid regions, (Elewa et al., 2017 and Hassan et al., 2017). As a result of droughtstressed, the plants have developed antioxidant enzymes such as, peroxidase (POD) and catalase (CAT) to protect themselves from reactive oxygen species. The peroxidase isozyme can be used as a marker for drought tolerance, (Hellal et al.,
2018). Peroxidase activity has a role in adjusting the osmotic cell, and its adjustment has been considered as the most important phenomenon to reduce the worst effects caused by the drought stress, (Guo et al., 2018). Hajihashemi et al. (2012) proved that stevia needs regular irrigation and their physiological and chemical characters are affected by drought-stressed and salinity of the irrigation water as well as differences in steviol glycosides percent have been shown with irrigation criteria, (Parris et al., 2016). In the coming years, demand for both stevia leaves and SV glys is expected to rise increasingly especially after EFSA Panel on Food Additives and Flavorings and the Joint FAO/WHO Expert Committee on Food Additives (JECFA) approval a SV glys as food additive. Moreover, global climate change leads to a sustainable expansion of reclaimed areas with optimal water usage due to insufficient water availability in many parts of the world as well there is a little information on the impact of steviol glycoside of stevia under stress situation. Ligno-cellulosic of sugarcane bagasse (SBP) based ecofriendly sustainable superabsorbent composites were synthesized by our scientific group at Faculty of Science, Tanta University, Egypt (a part of project entitled: "Superabsorbent polymer composite for agricultural applications". Funded by the Science and Technology Development Fund (STDF)._Project ID: 5842). The main objective of this study was to evaluate the effectiveness of a SBP to improve their physico-morpholigic characters and steviol glycosides of stevia plant under deficit irrigation. Therefore, peroxidase isozyme analysis as an indicator of tolerance to water deficit were evaluated.

\section{Materials and Methods}




\section{Stevia rebaudiana Bertoni}

The planting materials are cuttings of Stevia rebaudiana Bert. cultivar which was obtained from the Sabahia Agricultural Research Station (SARS), Sugar Crops Research Institute (SCRI), Agricultural Research Center (ARC), Ministry of Agriculture, Egypt

\section{Sugarcane bagasse}

The material was provided by a local sugar factory. Bagasse was dried in sunlight, it was ground and sieved under 30 mesh sieves and stored at room temperature in air tight polybag.

\section{Super absorbent polymer composite (SBP)}

The superabsorbent polymers composite from sugarcane bagasse (SBP) was synthesized using filler sugarcane bagasse, beaching and grafting of acrylamide with $\mathrm{N}, \mathrm{N}^{\prime}$ methylene bisacrylamide as cross linker and potassium persulfate and Attapulgite clay as initiator. The detailed method, characterization and swelling behavior of the resulted composite are previously reported by Kenawy et al. (2019).

\section{The chemical characteristics of the soil}

Soils are mixed a sandy with clay soil (2:1 $\mathrm{w} / \mathrm{w}$ ) and main characteristics are presented : 8.05 soil $\mathrm{pH}, 2.71 \mathrm{ds} / \mathrm{m}$ electrical conductivity soil, $6.1 \mathrm{meq} / \mathrm{L} \mathrm{Na}, 0.3 \mathrm{meq}$ $/ \mathrm{L} \mathrm{K}, 13.2 \mathrm{meq} / \mathrm{L} \mathrm{Ca}, 8.2 \mathrm{meq} / \mathrm{L} \mathrm{Mg}$, $3.2 \mathrm{meq} / \mathrm{L} \mathrm{HCO}, 6 \mathrm{meq} / \mathrm{L} \mathrm{CL}$ and $18.6 \mathrm{meq}$ $/ \mathrm{L} \mathrm{SO}_{4}$.

\section{Experimental procedures}

A pot experiment was carried out during two seasons 2017/2018 and 2018/2019 in the greenhouse of the Sabahia Agricultural Research Station (SARS), Alexandria, Egypt located at $31^{\circ} 19^{\prime} \mathrm{N}$ and $29^{\circ} 95^{\prime} \mathrm{E}$. Treatments were used the three amounts of super absorbent sugarcane bagasse polymer composite including $0.0,2.0$ and $4.0 \mathrm{~g}$ polymer per $5 \mathrm{~kg}$ of soils in plot with three irrigation regimes including irrigation at $100 \%$ of field capacity, and two deficit irrigation treatments 70 and $50 \%$ of treatment control. The pots were supplied with the chemical fertilizer doses as recommended for each crop by the Ministry of Agriculture and Land Reclamation of Egypt. The experimental design was completely randomized blocks (CRB) and the pots were left to grow under the normal growth conditions of the greenhouse $\left(32 / 23^{\circ} \mathrm{C} \pm 2\right)$ day/night, day length $12-14$ hours, relative humidity 66-73\%). Each crop was harvested individually according to its maturity duration. Three cuttings per year were collected of planting. The plants were cut uniformly $10 \mathrm{~cm}$ above the ground level. Morphological characters (plant height, number of branches per plant, number of leaves per branch, and fresh leaf yield). The leaves were dried in an oven at $50^{\circ} \mathrm{C}$ and kept until further analysis.

\section{Chemical analysis}

Ash and chlorophyll were determined according to the procedures of A.O.A.C. (2005). Total soluble carbohydrates in stevia extract were estimated by using Anthrone reagent according to the method of Yem and Willis (1954). Total steviosides (steviol glycoside) calculated by the equation as follow $\mathrm{TC}=7.56+0.96 \mathrm{TS}$. as described by Nishiyama et al. (1992). Dried stevia leaves in different treatment were ground on a $1 \mathrm{~mm}$ screen, prepared as pellets with $\mathrm{KBr}$ and analyzed using Perkin-Elmer system 1600 FTIR spectrophotometer in the region 650-4000 $\mathrm{cm}^{-1}$ to identify of steviol glycoside, (Hearn and Subedi, 2009).

\section{Peroxidase isozyme analysis}

In this work an attempt was carried out to investigate the isozyme patterns of the peroxidase in order to identify biochemical marker in Biotechnology Laboratory, 
Sabahia Agricultural Research Station (SARS). Leaf samples at thirteen-weeksold were chosen for studying peroxidase isozymes. Electrophoresis was used to separate the peroxidase isozyme patterns in the leaves of the stevia samples according to Mesbah et al. (2016). Measurement of bands was carried out using the computer program software TOTALLAB V.1.11.

\section{Effect of SBP on water use efficiency}

Water use efficiency (WUE) was expressed as the total stevia yield (kg pot) that could be produced from one cubic meter of water as the method described by Howell (2002). W.U.E. (g leaves/one $\mathrm{m}^{3}$ of water) = total stevia yield (kg pot)/water regime ( $\mathrm{m}^{3} /$ pot/year).

\section{Statistical analysis}

The data were analyzed by variances analysis (ANOVA), using the R, GLM procedure, (R Software, 2013). Means were compared by Duncan test at 5\% probability level. Figures were drawn by Excel (2010) Software.

\section{Results and Discussion}

Positive impacts of absorbent polymers composite on reducing the adverse effects of drought stress in crops.

\section{Morphologic characters and yield}

The mean of yearly values of morphology characters for stevia plant under different SBP and irrigation levels at the two seasons are shown in Table 1. It was noticed that the morphology characters were decreased by decreasing the irrigation level. Drought stress led to the reduction in stem diameter, shorter internodes and stem height, (Lovisolo and Schuber, 1998). This decrease may be either due to the decrease of cell elongation which led to a decrease in each cell turgor, cell volume and, eventually, cell growth. The SBP treatment with under deficit irrigation significant $(\mathrm{P} \leq$
0.05) was enhanced of these characters, resulting in an increased in fresh and dry plant yield. In each cutting, plant height irrigated at $100 \%$ was significantly higher than when irrigated at 70 , and $50 \%$, but not significant effects were observed in treatment with $2 \%$ or $4 \%$ SBP under same irrigation level (Table 1). The maximum height was obtained by $4 \%$ SBP treatment at $100 \%$ irrigation and its effects were less noticeable under deficit irrigation. Similarly, number of leaves was affected by decreasing the irrigation level that leading to a decrease in leaf yield as shown in Table 1. The SBP treatment at 2 and $4 \%$ significantly increased leaves number per branch by $19.18 \%$ and $17.18 \%$ respectively as compared to control at $100 \%$ irrigation. When using 2\% SBP under $70 \%$ and $50 \%$ deficit irrigation, the stevia leaves were increased by 47.78 and $38.89 \%$ respectively, as compared with that no treatment stevia. Increasing SBP to $4 \%$ increased the leaves by 44.45 and $62.94 \%$ under $70 \%$ and $50 \%$ deficit irrigation respectively this might be due to more availability of water. Which facilitate nutrient accumulation, maintained cell turgidity and increased number of leaves which converted more solar energy and fixed more $\mathrm{CO}_{2}$ to produce more photosynthesis, and thus greater growth, (Souch and Stephens, 1998). Superabsorbent composite application in soil improved plant canopy height, (Yousefian et al., 2018). This is consistent with the results by Rashad et al. (2020) found that the application of $1 \%$ of superabsorbent polymer with soil resulted in higher growth parameters of sweet pepper and plant capacity to positively respond to water drought conditions. However, $100 \%$ irrigation treatment with $2 \%$ SBP resulted in greater fresh leaf yield 
$(96.55 \mathrm{~g} /$ plant $)$ and dry leaf yield $(21.81$ $\mathrm{g} /$ plant), while the deficit irrigation 70 and $50 \%$ decreased fresh leaf yield 4.64 and $28.79 \%$ respectively, compared with $100 \%$ and resulted reduction in plant yield. Also, under deficit irrigation, SBP application had a positive effect on plant dry weight and increased it 1.5 and 1.32 fold when SBP was used 2 and $4 \%$, respectively, in $70 \%$ irrigation treatments as compared with control without SBP Fig.1 (a \& b) . Tavarini et al. (2015) reported that the reduced Canada stevia yield in reduced irrigated treatments can be due to stable accumulation of $\mathrm{CO}_{2}$ in biochemical photosynthesis reactions and to stable carbohydrates production. Plant dry weight showed higher values at the second cut than first cut in the same season while the plants of the second season were significantly lower than those of the same treatments of the first season and flower Fig (1-c). Results are agreement with the results by Abrisham et al. (2018) they stated that SAP enhanced soil and plant properties. Also, Gogo et al. (2020) observed that the treatment with superabsorbent polymer enhanced soil moisture, physiological and yield of pepper (Capsicum annuum L.) and eggplant (Solanum melongena L.).

\section{Quality characters}

Deficit irrigation in plants influences many biochemical and physiological processes. Chlorophyll content in plants is an important factor in determining photosynthetic capacity and depends on duration and severity of water stress and hence is affecting the metabolism of carbohydrates in plant, (Bray, 1997 and Kargar et al., 2017). The data in Table (1) shows that the irrigation level had effects on the chlorophyll content, ash and total soluble carbohydrate (TSC) of stevia's leaves. The deficit irrigation at $50 \%$ FC was caused a highly decline in both of the chlorophyll content and total soluble carbohydrate with increased of ash content in both seasons. Drought stress results in the decrease of the amount of chlorophyll, damage in the cell membrane and lack of balance between nutrient substances which results in the aging of cells of plant, (Santos et al., 2009). On the other hand, treatment of soil with SBP (2 or 4\%) enhanced chlorophyll content and total soluble carbohydrate under normal and deficit irrigation. There were significant $(\mathrm{p}<0.05)$ increased in chlorophyll content in plant treatment with $2 \%$ SBP with $9.15,13.81$ and $14.45 \%$ when compared to the untreated plants under 100, 70 and 50\% irrigation treatment, respectively (Table 1). Shangguan et al. (1999) reported that the application of SAP increased photosynthesis rate in intercellular carbon dioxide concentration and leaf water potential of plant. TSC and steviol glycoside (SVglys) values showed the same trend as chlorophyll content. Increasing water deficit from 100 to $50 \%$, significantly decreased TSC and SVglys values during the two growing seasons. Average TSC values decrease to $22.92,17.96$ and 14.77 $\%$ in the first season and 18.68, 15.67 and $14.82 \%$ in the second season under 100,70 and $50 \%$ irrigation level respectively, which can be regarded as a medium level compared with ranges reported by BarbetMassin et al. (2016). SBP application had a positive effect its values with significantly $(\mathrm{P} \leq 0.05)$ increased as compared to control without SBP under both irrigation systems. The highest mean values of TSC contents $(25.70 \%)$ were obtained from stevia plant treated with $2 \%$ SBP under $100 \%$ irrigation level in the two studied seasons as shown in Table (1). Calculated SVglys was high in soil amendment with $2 \%$ SAP $(15.60 \%)$ 
under $100 \%$ irrigation level and nearly closed in $70 \%$ irrigation level (15.02\%). There were no significant differences in SVglys contents between 2 and $4 \%$ SBP samples. According to Benhmimou et al. (2018), the water stress significantly reduced yield of steviol glycosides, which it was increased when application of biofertilizer. Similarly, Karimi et al. (2015) reported that the highest value of total steviol glycosides content was obtained in plant irrigated at $60 \%$ field capacity. Moreover, the means of ash content of stevia as depicted in Table 1 were range from 8.76 to $13.82 \%$. This variation may be due to the difference in SBP and irrigation levels. However, there was non-significant variation in chlorophyll, ash, TSC and SVglys among 2 and 4\% SBP doses under both the irrigation level.

\section{Infrared spectroscopy analysis as a measure of steviol glycoside content}

The infrared (IR) spectroscopy was used to evaluate the efficiency of the SBP on steviol glycoside (SVglys) content in stevia leaves samples. The infrared absorption method is a considered as rapid, sensitive, powerful and accurate analytical methods for investigating structural, functional, and compositional changes in molecules that can be of benefit to determine the steviol glycoside value, (Martono et al., 2018). IR spectra of treatment dried powder stevia leaves were presented in figure (2). IR spectra of stevia showed a strong wide and intense absorption bands at range 3500$3200 \mathrm{~cm}^{-1}$ corresponded to the stretching vibration of the $-\mathrm{OH}$ stretching and was associated with the presence of hydrogen bond. Absorption at $2924 \mathrm{~cm}^{-1}$ was characteristic of stretching- $\mathrm{CH}$ sp3 bond. Intense peaks at 1731 and $1634 \mathrm{~cm}^{-1}$ corresponded to $\mathrm{C}=\mathrm{O}$ stretching in esters. Bending vibrational of $-\mathrm{CH}$ bond was observed at 1570 and $1378 \mathrm{~cm}^{-1}$. C-O-C stretching in esters $\left(1072-1254 \mathrm{~cm}^{-1}\right)$ high intense peaks at 1072 and $1031 \mathrm{~cm}^{-1}$ corresponded to $\mathrm{C}-\mathrm{O}$ derived from steviol glycoside and was characteristic absorption band of the glycosidic bond. Finally, peaks at $812 \mathrm{~cm}^{-1}$ and $606 \mathrm{~cm}^{-1}$ were recognized to bending vibration of $=\mathrm{CH}$ and $=\mathrm{CH} 2$ bonds respectively, (Chranioti et al., 2016). The spectrum displayed a wide and intense absorption at $3500-3200 \mathrm{~cm}^{-1}$ typical corresponded to the stretching vibration of hydroxyl groups associated with the presence of hydrogen bond which can supported by concentration of SVglys. The decreasing or increasing intensities of bands in the IR spectrum in the range 3500 $-2855 \mathrm{~cm}^{-1}$ can function as a measure for the efficiency of the SBP treatment. These intensities of the biomass spectra was higher in SBP samples compared to the spectrum untreated samples. These results of IR spectrum are supported by the calculated SVglys yield for the same samples. Results indicated that water stress, variety and their interaction had significant effects on steviol glycosides content.

\section{Water use efficiency}

Results in Figure 3 showed an increase in WUE with SBP treatment under the deficiency water supply, the WUE changed slightly following the application of SBP in soil under $100 \%$ irrigation but SBP application was positive on WUE under deficit irrigation conditions (Fig. 3). The amount of WUE increased by $30.14 \%$ and 32.97 when applied 2 and 4\% SBP in the soil compared to the untreated control under $70 \%$ irrigation level. The highest WUE (1.23 g/pot) was recorded with $4 \%$ SBP under 50\% irrigation closely followed under $70 \%$ irrigation $(1.22 \mathrm{~g} / \mathrm{pot})$. The results of the second season showed that, the use $70 \%$ irrigation combined with 2 and 
4\% SBP gave the highest water use efficiency of 1.077 and $1.107 \mathrm{~g} / \mathrm{m}^{-3}$, respectively (Figure 3 ). Similar results were obtained by Mahalleh et al. (2011) they reported that using SAP under water deficit treatments of corn increased water use efficiency. The superabsorbent polymers may be take up water and gradually release it back to the soil to balance the lower water reservoir and has reduced the adverse influence of deficit irrigation.

\section{Peroxidase isozyme changes response to water stress and SBP levels}

The peroxidase isozyme analysis showed that water deficit and different SBP affected peroxidase isozyme and was observed for each parameter band existence, band volume, peak height and R.f. (Fig. 4-a) illustrates six gel electrophoretic isozyme patterns of stevia plant. The data indicated that there were nine different bands migrated towards the cathode (Fig. 4-b); while there were four different bands migrated towards the anode (Fig. 4-c) . Band existence, band volume, peak height and R.f. parameter were found to be different from all samples (Table 2). The interpretation of isozyme band pattern, samples were classified into six categories and coding as follows: $\left(\mathrm{C}_{1}, \mathrm{C}_{2}\right.$ and $\left.\mathrm{C}_{3}\right)$ which means control under different water irrigation (100, 70 and 50\%, respectively), ( $\mathrm{T}_{4}$ and $\mathrm{T}_{5}$ were treated stevia with 2 and $4 \%$ SBP, respectively) under $70 \%$ water irrigation and $\mathrm{T}_{6}$ was treated stevia with $4 \%$ SBP under $50 \%$ of water irrigation. Samples were subjected to electrophoresis and the obtained results would be illustrated as follows: band No.1, 2, 4, 7, 8 and 9 in the cathode side were absent in control samples, while band No.3 and 6 in the cathodal side was absent in the treatment sample plants (Table 2), giving accurate evidence that differential gene expression was achieved. Table 2 shows the band No.9 had R.f. value of about 0.953 ; while band No.1 had R.f. value of about 0.111 in the cathodal side. On the other hand, band No.1 and 2 in the anodal side was found in almost treated materials, while band No. 4 presented only in most control samples. Data showed that bands No. 1 and 2 had R.f. values of about 0.086 and 0.305 ; respectively while band No.3 and 4 which had R.f. value of about 0.410 and 0.509 ; respectively as mention in Table 2 . Weising et al. (1995) reported that isozymes are enzymes that convert the same chemical substrate but are not necessarily products of the same gene. Isozymes may be active at different life stages or in different cell component. Kolodziejczak and Krzakowa (2003) suggested that cathodic peroxidase system is controlled by four independent genes, of which only one is polymorphic as well as anodal bands were used to investigate the differences between bolting and non-bolting plants (Ghonema, 2005). Bai et al. (2006) also observed that level of antioxidants and the activities of antioxidant enzymes such as POD increased in plants under stressed conditions and in several cases their 
Grad et al., SVU-International Journal of Agricultural Sciences, 3 (2): 22-36, 2021

Table1. Effect of sugarcane bagasse polymer (SBP) on some morphologic and quality characters of stevia plant under deficit irrigation

\begin{tabular}{|c|c|c|c|c|c|c|c|c|c|c|c|}
\hline \multirow[t]{2}{*}{ Season } & \multicolumn{2}{|c|}{ Treatment } & \multicolumn{5}{|c|}{ Morphologic characters } & \multicolumn{4}{|c|}{ Quality characters } \\
\hline & $\begin{array}{l}\text { Irrigation } \\
\text { levels }\end{array}$ & SBP & $\begin{array}{c}\text { Plant } \\
\text { height }(\mathrm{cm})\end{array}$ & $\begin{array}{c}\text { Number of } \\
\text { branches } \\
\text { /plant }\end{array}$ & $\begin{array}{c}\text { Number of } \\
\text { leaves/branch }\end{array}$ & $\begin{array}{l}\text { Plant fresh } \\
\text { weight }(\mathrm{g})\end{array}$ & $\begin{array}{l}\text { Plant dry } \\
\text { weigh }(g)\end{array}$ & $\begin{array}{c}\text { Chlorophyll } \\
\%\end{array}$ & $\begin{array}{c}\text { Ash } \\
\%\end{array}$ & $\begin{array}{c}\text { Total } \\
\text { soluble } \\
\text { carbohydrate }\end{array}$ & $\begin{array}{c}\text { Steviol } \\
\text { glycoside } \\
\% \\
\end{array}$ \\
\hline \multirow[t]{13}{*}{$2017 / 18$} & 100 & 0 & $58.2^{\mathrm{b}}$ & $39.33^{b}$ & $33^{b}$ & $83.33^{b}$ & $18.29^{b}$ & $38.7^{\mathrm{b}}$ & $8.93^{\mathrm{b}}$ & $22.92^{b}$ & $16.00^{\mathrm{b}}$ \\
\hline & & 2 & $62.5^{\mathrm{a}}$ & $45^{\mathrm{a}}$ & $39.33^{\mathrm{a}}$ & $96.55^{\mathrm{a}}$ & $21.81^{\mathrm{a}}$ & $42.24^{\mathrm{a}}$ & $8.58^{\mathrm{a}}$ & $25.70^{\mathrm{a}}$ & $18.89^{\mathrm{a}}$ \\
\hline & & 4 & $64.1^{\mathrm{a}}$ & $45.33^{\mathrm{a}}$ & $38.67^{\mathrm{a}}$ & $94.74^{\mathrm{a}}$ & $20.67^{\mathrm{a}}$ & $42.63^{\mathrm{a}}$ & $8.78^{\mathrm{a}}$ & $24.96^{\mathrm{a}}$ & $18.12^{\mathrm{a}}$ \\
\hline & & Mean & 61.6 & 43.22 & 37 & 91.54 & 20.26 & 41.19 & 8.76 & 22.79 & 17.67 \\
\hline & 70 & 0 & $42.75^{b}$ & $36^{\mathrm{b}}$ & $22.33^{\mathrm{b}}$ & $70.82^{b}$ & $16.26^{\mathrm{b}}$ & $37.22^{b}$ & $9.57^{b}$ & $17.96^{\mathrm{b}}$ & $10.83^{b}$ \\
\hline & & 2 & $58.5^{\mathrm{a}}$ & $43.33^{\mathrm{a}}$ & $33^{\mathrm{a}}$ & $92.07^{\mathrm{a}}$ & $19.89^{\mathrm{a}}$ & $42.36^{\mathrm{a}}$ & $10.86^{\mathrm{a}}$ & $24.50^{\mathrm{a}}$ & $17.65^{\mathrm{a}}$ \\
\hline & & 4 & $59.1^{\mathrm{a}}$ & $44^{\mathrm{a}}$ & $37^{\mathrm{a}}$ & $94.13^{\mathrm{a}}$ & $19.84^{\mathrm{a}}$ & $41.33^{\mathrm{a}}$ & $10.99^{\mathrm{a}}$ & $23.89^{\mathrm{a}}$ & $17.01^{\mathrm{a}}$ \\
\hline & & Mean & 53.45 & 41.11 & 30.78 & 85.67 & 18.66 & 40.30 & 10.47 & 22.31 & 15.16 \\
\hline & 50 & 0 & $38.5^{\mathrm{b}}$ & $20.67^{b}$ & $18^{\mathrm{b}}$ & $46.3^{b}$ & $9.95^{b}$ & $35.35^{b}$ & $10.7^{\mathrm{b}}$ & $14.77^{\mathrm{b}}$ & $7.51^{\mathrm{b}}$ \\
\hline & & 2 & $40.45^{\mathrm{a}}$ & $31.67^{\mathrm{a}}$ & $25^{\mathrm{a}}$ & $62.22^{\mathrm{a}}$ & $13.22^{\mathrm{a}}$ & $40.46^{\mathrm{a}}$ & $10.88^{a}$ & $17.21^{\mathrm{a}}$ & $10.05^{\mathrm{a}}$ \\
\hline & & 4 & $42.8^{a}$ & $39.33^{\mathrm{a}}$ & 29.33 & $67.75^{\mathrm{a}}$ & $15.25^{\mathrm{a}}$ & $36.85^{\mathrm{a}}$ & $10.71^{\mathrm{a}}$ & $18.84^{\mathrm{a}}$ & $14.08^{\mathrm{a}}$ \\
\hline & & Mean & 40.58 & 30.56 & 24.11 & 58.76 & 12.81 & 37.55 & 10.76 & 16.94 & 10.54 \\
\hline & & LSD mean & 1.808 & 2.215 & 1.789 & 2.463 & 1.027 & 4.349 & 0.868 & 6.009 & 4.837 \\
\hline \multirow[t]{13}{*}{$2018 / 19$} & 100 & 0 & $51.7^{\mathrm{b}}$ & $34^{\mathrm{b}}$ & $31.33^{\mathrm{b}}$ & $79.45^{b}$ & $16.64^{\mathrm{b}}$ & $38.4^{\mathrm{b}}$ & $11.58^{b}$ & $18.69^{\mathrm{b}}$ & $11.59^{\mathrm{b}}$ \\
\hline & & 2 & $53.9^{a}$ & $39.67^{\mathrm{a}}$ & $32^{\mathrm{a}}$ & $87.43^{\mathrm{a}}$ & $19.24^{\mathrm{a}}$ & $41.53^{\mathrm{a}}$ & $12.48^{\mathrm{a}}$ & $22.54^{\mathrm{a}}$ & $15.60^{\mathrm{a}}$ \\
\hline & & 4 & $55.3^{a}$ & $42^{\mathrm{a}}$ & $33.33^{\mathrm{a}}$ & $88.55^{\mathrm{a}}$ & $17.68^{\mathrm{a}}$ & $42.19^{a}$ & $12.62^{a}$ & $21.72^{\mathrm{a}}$ & $14.75^{\mathrm{a}}$ \\
\hline & & Mean & 53.63 & 38.56 & 32.22 & 85.14 & 17.85 & 41.04 & 12.22 & 20.65 & 13.98 \\
\hline & 70 & 0 & $40.6^{b}$ & $28^{b}$ & $21^{b}$ & $60.68^{b}$ & $13.8^{\mathrm{b}}$ & $37.77^{b}$ & $12.52^{b}$ & $15.67^{b}$ & $8.45^{b}$ \\
\hline & & 2 & $53.2^{\mathrm{a}}$ & $37^{\mathrm{a}}$ & $29^{a}$ & $82.9^{a}$ & $17.16^{\mathrm{a}}$ & $41.86^{\mathrm{a}}$ & $13.97^{\mathrm{a}}$ & $21.98^{\mathrm{a}}$ & $15.02^{\mathrm{a}}$ \\
\hline & & 4 & $51.9^{\mathrm{a}}$ & $40.33^{a}$ & $32^{\mathrm{a}}$ & $85.31^{\mathrm{a}}$ & $17.22^{\mathrm{a}}$ & $41.9^{a}$ & $13.62^{\mathrm{a}}$ & $22.09^{\mathrm{a}}$ & $15.13^{\mathrm{a}}$ \\
\hline & & Mean & 48.57 & 35.11 & 27.33 & 76.29 & 16.06 & 40.84 & 13.37 & 19.91 & 12.87 \\
\hline & 50 & 0 & $26^{b}$ & $19^{b}$ & $16.67^{b}$ & $43.58^{b}$ & $9.74^{b}$ & $36.04^{b}$ & $14.97^{b}$ & $14.82^{b}$ & $7.56^{b}$ \\
\hline & & 2 & $33.6^{\mathrm{a}}$ & $31.67^{\mathrm{a}}$ & $21.33^{\mathrm{a}}$ & $57.07^{\mathrm{a}}$ & $11.88^{\mathrm{a}}$ & $42.25^{\mathrm{a}}$ & $13.48^{\mathrm{a}}$ & $16.55^{\mathrm{a}}$ & $9.36^{\mathrm{a}}$ \\
\hline & & 4 & $37.5^{\mathrm{a}}$ & $34.33^{\text {a }}$ & $22.67^{\mathrm{a}}$ & $59.28^{a}$ & $12.57^{\mathrm{a}}$ & $36.83^{a}$ & $13.01^{\mathrm{a}}$ & $16.18^{\mathrm{a}}$ & $8.98^{a}$ \\
\hline & & Mean & 32.37 & 28.33 & 20.22 & 53.31 & 11.39 & 38.7 & 13.82 & 15.85 & 8.63 \\
\hline & & LSD mean & 2.173 & 1.489 & 2.478 & 3.026 & 3.711 & 4.439 & 1.588 & 4.711 & 4.393 \\
\hline
\end{tabular}


Table 2. Analysis of electrophoretic data obtained from six leaf samples control and treated of stevia plant for cathodal and anodal band.

\begin{tabular}{|c|c|c|c|c|c|c|c|c|c|c|c|c|c|c|c|c|c|c|c|c|c|c|c|c|c|c|c|c|c|c|c|c|c|c|c|c|c|c|c|}
\hline \multirow{2}{*}{ Sample } & \multicolumn{3}{|c|}{ Band $1(-)$} & \multicolumn{3}{|c|}{ Band 2 (-) } & \multicolumn{3}{|c|}{ Band 3 (-) } & \multicolumn{3}{|c|}{ Band 4 (-) } & \multicolumn{3}{|c|}{ Band 5 (-) } & \multicolumn{3}{|c|}{ Band 6 (-) } & \multicolumn{3}{|c|}{ Band 7 (-) } & \multicolumn{3}{|c|}{ Band 8 (-) } & \multicolumn{3}{|c|}{ Band 9 (-) } & \multicolumn{3}{|c|}{ Band $1(+)$} & \multicolumn{3}{|c|}{ Band $2(+)$} & \multicolumn{3}{|c|}{ Band $3(+)$} & \multicolumn{3}{|c|}{ Band $4(+)$} \\
\hline & $\mathrm{Vol}_{\mathrm{h}}$ & $\begin{array}{l}\text { Peak } \\
\text { height. }\end{array}$ & R.f & Vol. & $\begin{array}{c}\text { Peak } \\
\text { height }\end{array}$ & $\mathrm{r}$ & Vol. ${ }_{\mathrm{h}}$ & & R.f. & $\mathrm{v}$ & $\begin{array}{c}\text { Peak } \\
\text { height. }\end{array}$ & R.f. & v & $\begin{array}{l}\text { ak } \\
\text { ght. }\end{array}$ & R.f. & & $\begin{array}{c}\text { Peak } \\
\text { height. }\end{array}$ & & & $\begin{array}{l}\text { Peak } \\
\text { height. }\end{array}$ & R.f. & $\mathrm{Vol}_{\mathrm{h}}$ & $\begin{array}{l}\text { Peak } \\
\text { height. }\end{array}$ & R.f. & Vol. $_{h}$ & $\begin{array}{l}\text { Peak } \\
\text { height. }\end{array}$ & R.f. & & $\begin{array}{c}\text { Peak } \\
\text { height. }\end{array}$ & & & $\begin{array}{l}\text { Peak } \\
\text { height }\end{array}$ & R. & & $\begin{array}{l}\text { Peak } \\
\text { leight }\end{array}$ & & & $\begin{array}{l}\text { Peak } \\
\text { height }\end{array}$ & \\
\hline $\mathrm{C}$ & - & . & - & - & 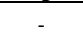 & - & - & - & - & - & 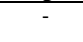 & 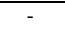 & - & & - & & 30.350 & 0.680 & & 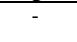 & 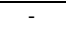 & - & 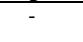 & - & - & & - & & 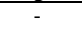 & 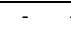 & & & - & & & -3 & 35.2 & 6.55 & 0.548 \\
\hline C & - & - & - & - & 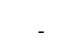 & - & - & - & - & - & - & 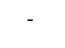 & & & 0.502 & 127. & 62.390 & 0.706 & & - & - & - & - & 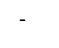 & - & - & - & 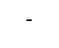 & - & - & - & - & - & & & 3 & 31.2 & 3.150 & 0.509 \\
\hline & 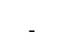 & - & - & - & 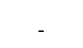 & - & & 65.6 & & - & 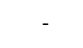 & - & - & 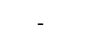 & -3 & 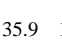 & 60 & 0.716 & - & 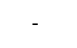 & - & - & - & 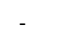 & 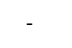 & - & - & - & 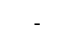 & - & - & - & - 10 & & 3.260 & 0.410 & 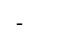 & - & 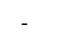 \\
\hline & 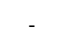 & - & - & - & 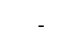 & - & - & - & - & 226. & 43.1 & 0.361 & & - & - & - & - & - & 43.7 & 13.81 & 0.763 & & 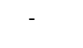 & - & 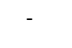 & 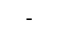 & - & - & - & - & - & - & $\begin{array}{l}-\quad 17 \\
-1\end{array}$ & 75.43 & 3.710 & 0.423 & & - & \\
\hline & 52.2 & 19.7 & 0.111 & - & 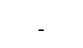 & - & - & - & - & . & - & - & 448 & & 0.475 & 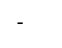 & 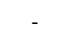 & - & - & 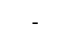 & - & 85.2 & 29.600. & 0.916 & - & - & - & 20.1 & 0.000 & 0.12356 & & 1.290 & 0.341 & - & - & - & - & - & \\
\hline 10 & - & - & -5 & 55.4 & 15.3 & 0.175 & & 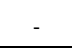 & . & - & 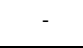 & 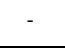 & 174.0 & 38.7 & 0.468 & - & - & - & 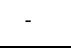 & & & . & - & - & 43.8 & 26.8 & 0.953 & 19.0 & $0.00 \quad 0$ & 0.08664 & & $\begin{array}{ll}9.51 \quad 0 . \\
\end{array}$ & 0.305 & 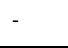 & & - & - & - & - \\
\hline
\end{tabular}




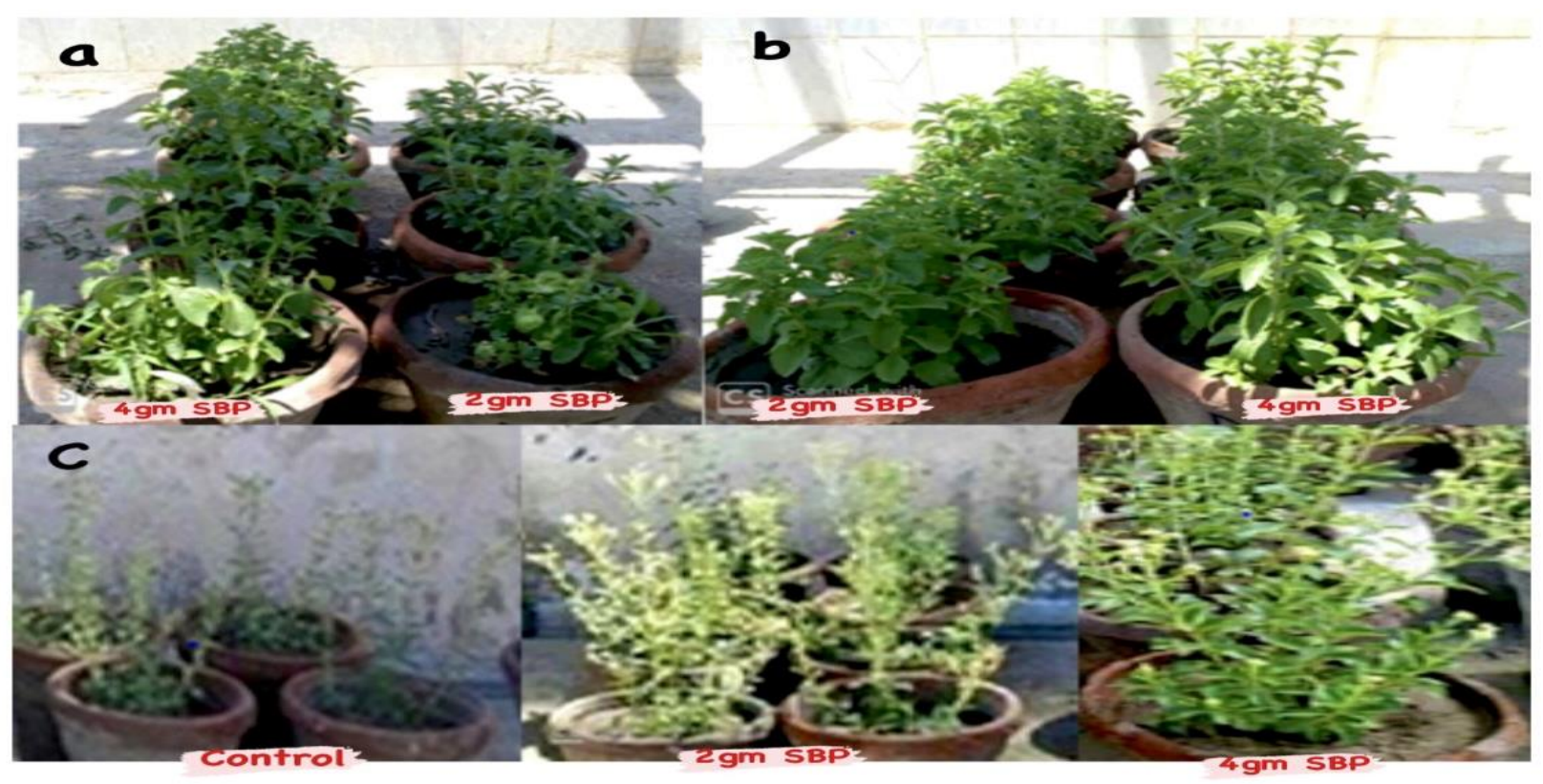

Figure1. The effect of the superabsorbent polymer composite on the morphological characters of Stevia rebaudiana Bert under 70\% water level 2018/19 season after 90 day (a) first cut (b) second cut in first season (c) second cut in second season.

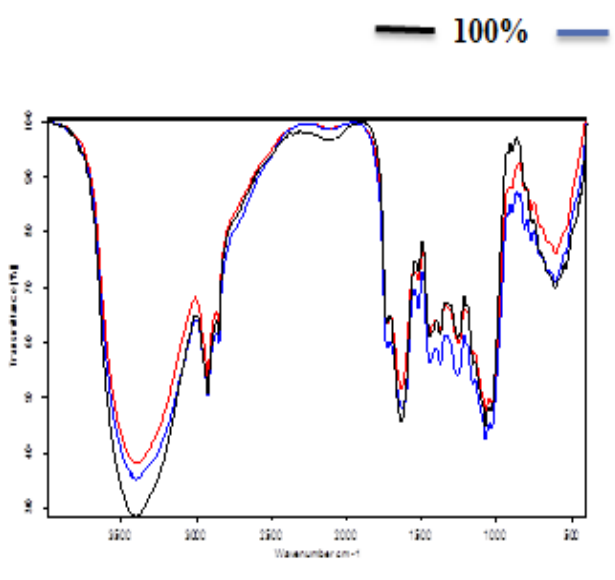

$2 \% \mathrm{SBP}$

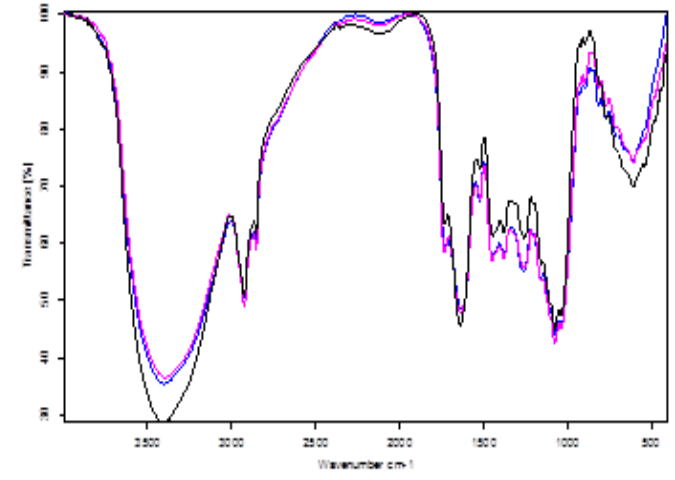

$4 \%$ SBP

Figure 2. IR spectrum of stevia leaves at 4months planting in soil amendment with SBP under different irrigation levels. 


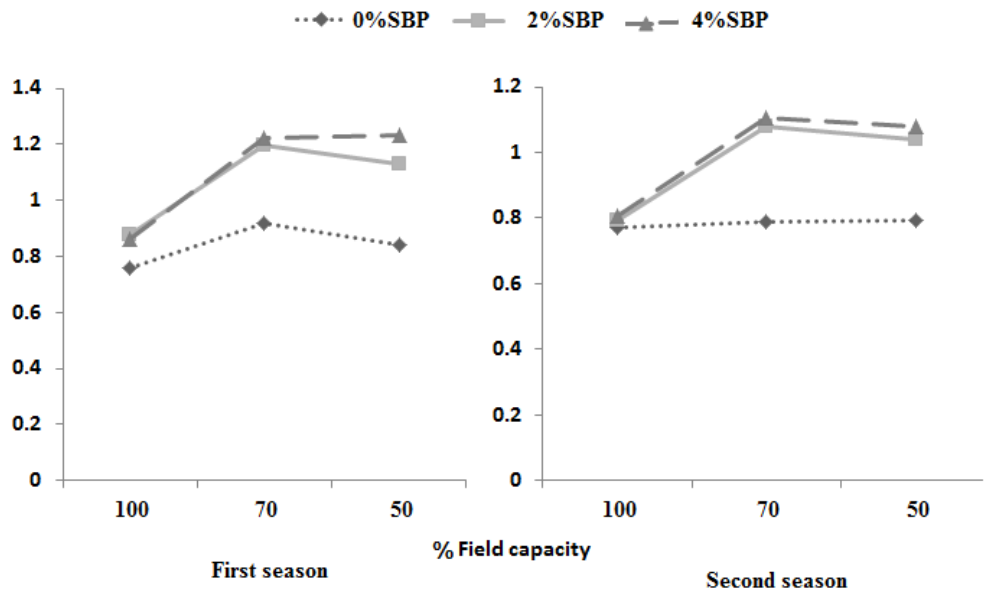

Figure 3. Effect of deficit irrigation on water use efficiency on stevia grown in soil amendment with SBP during two seasons.
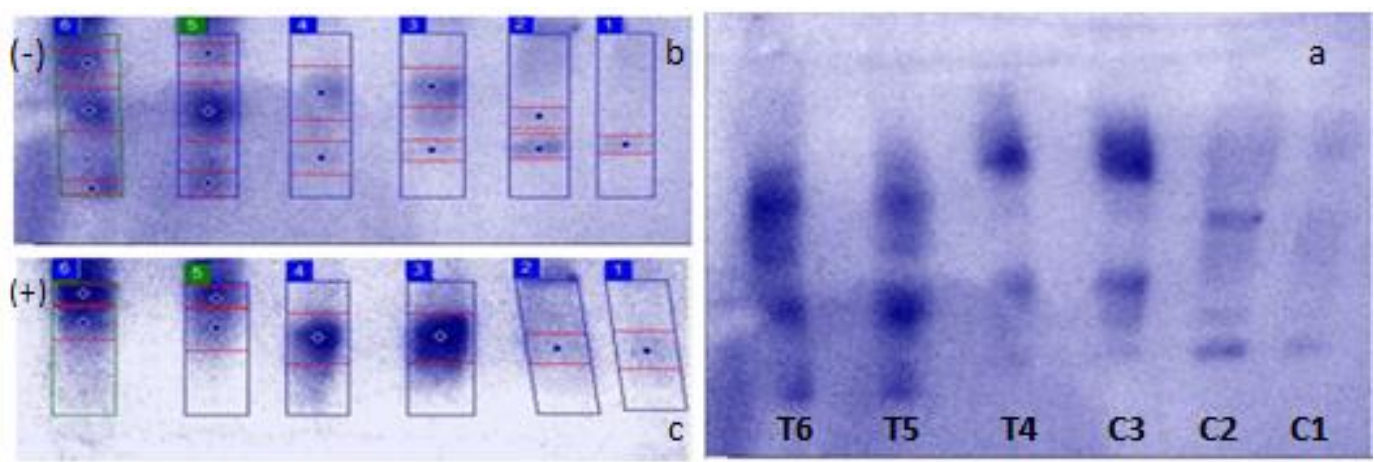

Figure 4. Isozyme patterns (a), and their analysis of electrophoretic cathodal peroxidase bands (b) \& anodal bands (c) obtained from the six leaf samples control and treated of stevia plant.

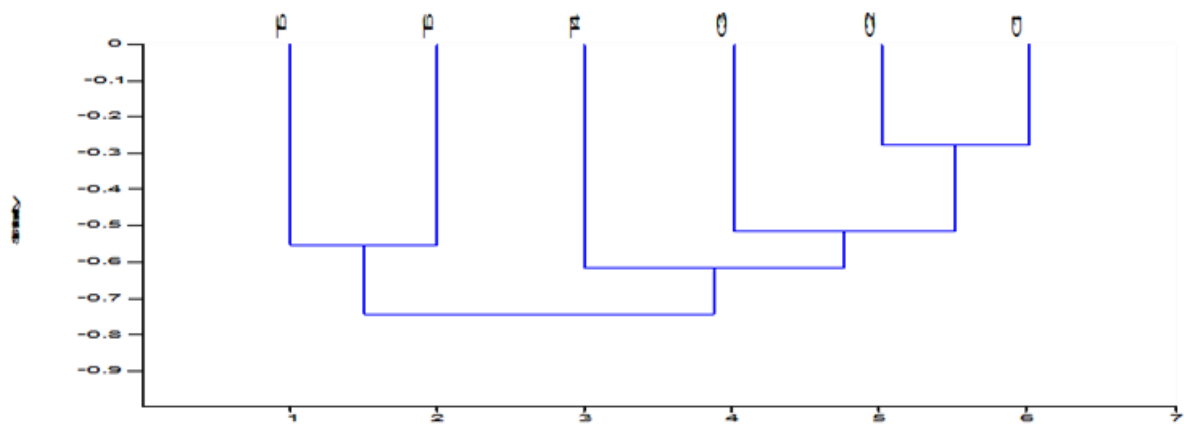

Figure 5. Dendrogram of cluster analysis for stevia variety based on (0 and 1) data._Whereas: (C): Control - (T): Treatment. 
activity correlated well with enhanced tolerance. Helmy et al. (2016) investigate antioxidant activity of Stevia rebaudiana under salt stress and the ability of tolerance of stevia plants to salt stress. Antioxidant enzyme activity (peroxidase) was assayed during the different cutting times. There is an increase in antioxidant enzyme activity under the high level of salt compared to untreated control plants. Figure 5 shows dendrogram of cluster analysis based on (0 and 1) data employing the figure shows that there were two main different clusters in the dendrogram tree.

The analysis was capable to classify the studied six plant leaf samples into two clusters, cluster No. 1 contained two plant samples ( $\mathrm{T}_{5}$ and $\mathrm{T}_{6}$ ) these samples belong to the treated plants in stevia variety. Cluster No. 2 contained four plant samples $\left(\mathrm{T}_{4}, \mathrm{C}_{3}, \mathrm{C}_{2}\right.$, and $\left.\mathrm{C}_{1}\right)$, this cluster contain all three-control plant sample in a small branch together and treatment sample number four on the other side which close to the other two treatments. Abdelsalam et al. (2020) studied the activities of antioxidant enzymes intensively and the results provide strong similarities between the Acacia species were examined, and the obtained data were subjected to cluster analysis.

\section{Conclusion}

The superabsorbent polymers composite from sugarcane bagasse (SBP) was improved of stevia productivity under deficit irrigation conditions, and it showed enhance in peroxidase isozyme system which can be used as a biomarker for characterizing drought stress tolerance.

\section{References}

A.O.A.C. (2005) 'Official method of Analysis. 18th Edition, Association of Officiating
Analytical Chemists' Washington, D.C., Method 935.14 and 992.24. https://www.scirp.org/(S(351jmbntvnsjt1 aadkposzje))/reference/ReferencesPapers. aspx?ReferenceID=2033299.

Abdelsalam, N.R., Ali, H.M., Salem, M.Z.M., and El-Wakil, H.E. (2020). 'Quantitative and qualitative genetic studies of some acacia species grown in Egypt', Plants, 9 (2),

pp. 243. doi.org/10.3390/plants9020243.

Abrisham, E.S., Jafari, M., Tavili, A., Rabii, A., Chahoki, M.A.Z., Zare, S., Egan, T., Yazdanshenas, H., Ghasemian, D., and Tahmoures, M. (2018) 'Effects of a superabsorbent polymer on soil properties and plant growth for use in land reclamation', Arid Land Research and Management, 32, pp. 407-420.

Bai, L.-P., Sui, F.-G., Ge, T.-D., Sun, Z.-H., Lu, Y.-Y., and Zhou, G.-S. (2006) 'Effect of soil drought stress on leaf water status, membrane permeability and enzymatic antioxidant system of maize', Pedosphere, 16, pp. 326-332. doi.org/10.1016/S10020160(06)60059-3.

Barbet-Massin, C., Giuliano, S., Alletto, L., Dayde, J., and Berger, M. (2016) 'Towards a semi-perennial culture of Stevia rebaudiana (Bertoni) under temperate climate: effects of genotype, environment and plant age on steviol glycoside content and composition', Genet Resour Crop Evol, 63, pp. 685-694. doi.10.1007/s10722-015-0276-9.

Benhmimou, A., Ibriz, M., Al-Faïz, C., Gaboun, F., Shaimi, N., Amchra, F.Z., and Lage, M. (2018) 'Effects of water stress on growth, yield, quality and physiological responses of two stevia (Stevia 
rebaudiana Bertoni) varieties in Rabat region, Morocco', Asian J Agri \& Bio, 6 (1), pp. 21-34. https://www.researchgate.net/publication/ 324150164.

Bray, E.A. (1997) 'Plant responses to water deficit', Trends Plant Science, 2 (2), pp. 48-54.doi.org/10.1016/S1360-1385(97) 82562-9.

Chranioti, C., Chanioti, S., and Tzia, C. (2016) 'Comparison of spray, freeze and oven drying as a means of reducing bitter aftertaste of steviol glycosides (derived from Stevia rebaudiana Bertoni plant)evaluation of the final products', Food Chem, 190, pp. 1151-1158. doi.org/10.1016/j.foodchem.2015.06.083.

Elewa, T.A., Sadak, M.S., and Saad, A.M. (2017) 'Proline treatment improves physiological responses in quinoa plants under drought stress', Biosci Res, 14 (1), pp. 21-33.

El-Haggar, S.M., and El-Gowini, M.M. (2005) 'Comparative Analysis of alternative fuels for Sugarcane industry in Egypt' 1st Ain Shams International Conference on Environmental Engineering. Cairo, Egypt.

Ghaheri, M., Miraghaee, S., Babaei, A., Mohammadi, B., Kahrizi, D., Haghighi, Z.M.S., and Bahrami, G. (2018) 'Effect of Stevia rebaudiana Bertoni extract on sexual dysfunction in Streptozotocininduced diabetic male rats', Cellular and Molecular Biology, (Noisy-le-Grand, France) 64, pp. 6-10. doi:10.14715/ cmb/ 2018.64.2.2.

Ghonema, M.A. (2005) 'Genetical and cytological studies on bolting in sugar beet Beta vulgaris L. plant'. Ph.D. Thesis. Fac. Agric. Alexandria University.

Gogo, E.O., Mnyika, A.W., and Mbuvi, S.M. (2020) 'Superabsorbent polymer and rabbit manure improve soil moisture, growth and yield of eggplant (Solanum melongena L.)', NASS Journal of Agricultural Sciences, 2 (1), pp. 12-20. doi.10.36956/njas.v2i1.93.

Guo, Y.Y., Yu, H.Y., Yang, M.M., Kong, D.S., and Zhang, Y.J. (2018) 'Effect of drought stress on lipid peroxidation, osmotic adjustment and antioxidant enzyme activity of leaves and roots of Lycium ruthenicum Murr', seedling. Russ. J. Plant Physiol, 65 (2), pp. 244-250. doi.org/10.1134/S1021443718020127.

Hajihashemi, S., Geuns, J.M.C., and Ehsanpour, A. (2012) 'Physiological analysis of Stevia rebaudiana after treatment with polyethyleneglycol, paclobutrazol and gibberellic acid. In Proceedings of the 6th Eustas Stevia Symposium, Stevia: Six months beyondauthorisation (ed JMC Geuns), pp 157-180, KULeuven, Belgium,ISBN: 978907425320.

Hassan, M. A., Chaura, J., Donat-Tores, M.P., Boscaiu, M., and Vicente, O. (2017) 'Antioxidant responses under salinity and drought in three closely related wild monocots with different ecological optima', AoB plants, 9 (2), doi: 10.1093/ aobpla/plx009.

Hearn, L., and Subedi, P. 2009. 'Determining levels of steviol glycosides in the leaves of Stevia rebaudiana by near infrared reflectance spectroscopy', Journal of Food Composition and Analysis, 22, pp. 165-168. 
Hellal, F.A., El-Shabrawi, H.M., El-Hady, M.A., Khatab, I.A., El-Sayed, S.A.A., and Abdelly, C. (2018) 'Influence of PEG induced drought stress on molecular and biochemical constituents and seedling growth of Egyptian barley cultivars', $J$. Genet. Eng. Biotechnology, 16 (1), pp. 203-212.

doi.org/10.1016/j.jgeb.2017.10.009.

Helmy, B.F., Abdelsalam, N.R., Ghonema M.A., and Khalid, A.E. (2016) 'Morphological changes and antioxidant activity of Stevia rebaudiana under salt stress', Alexandria Science Exchange Journal, 37 (2), pp. 326-336. http://alexexch.org/File/2016003702/En/ 2206.pdf.

Howell, T.A. (2001) 'Enhancing water use efficiency in irrigated agriculture', Agronomy Journal, 93 (2), pp. 281-9. doi:10. 2134/agronj2001.932281x.

Kargar, M., Suresh, R., Legrand, M., Jutras, P., Clark, O.G., and Prasher, S.O. (2017) 'Reduction in water stress for tree saplings using hydrogels in soil', Journal of Geoscience and Environment Protection, 5, pp. 27-39. doi:10.4236/ gep.2017.51002.

Karimi, M., Ahmadi, A., Hashemi, J., Abbasi, A., Tavarini, S., Pompeiano, A., Guglielminetti, L., and Angelini, L.G. (2015) 'The positive role of steviol glycosides in stevia (Stevia rebaudiana Bertoni) under drought stress condition', Plant Biosyst, doi.org/10.1080/11263504. 2015.1056857.

Kenawy, E., Rashad, M., and Hosny, A. (2019)

'Preparation, characterization and swelling behavior of superabsorbent composite based on rice husk', 5th
International Conference on Scientific Research: Renewable Energy and Water Sustainability, 26-9 Mar, Sharm Elshikh. Kolodziejczak, M., and Krzakowa, M. (2003) 'Variability of cathodic peroxidases in sugar beet (Beta vulgaris L.) cultivars', Journal of Applied Genetics, 44 (1), pp. 55-62. PMID: 12590181

Lovisolo, C., and Schubert, A. (1998) 'Effect of water stress on vessel size and xylem hydraulic conductivity in Vitis vinifera L', J. Exp. Bot, 49, pp. 693-700.

Mahalleh, J.K., Abad, H.H.S., Nourmohammadi, G., Darvish, F., Haravan, I.M., and Valizadegan, E. (2011) 'Effect of superabsorbent polymer (Tarawat A200) on forage yield and qualitative characters in corn under deficit irrigation condition in Khoy zone (northwest of Iran)', Advances in Environmental Biology, 5 (9), pp. 25792587.https://www.researchgate.net/public ation/288444105.

Martono, Y., Suryasatriya, T., and Ferdy, S.R. (2018) 'Determination of stevioside and rebaudioside $\mathrm{A}$ in Stevia rebaudiana Bertoni leaves using near Infrared Spectroscopy and Multivariate Data analysis', Indones. J. Chem, 18 (4), pp. 664 - 671. doi.org\%2F10.22146\% 2Fijc. 25580.

Mesbah H.A., El-Sayed, N.A.A., Awad, A.I., and El-Banna, B.S.M. (2016) 'Esterase isozyeme as an indicator for the genetic variations of Bactrocera zonata (Saunders)', Alex. Sci. Exchange J, 37(2), pp. 127-132.

Nishiyama, P., Alvarey, M., and Vieira, L. (1992) 'Quantitative analysis of stevioside in the leaves of Stevia rebaudiana by Near 
Infrared reflectance spectroscopy', J. Sci. Food Agric, 59, pp. 277-281.

Pal, P.K., Kumar, R., Guleria, V., Mahajan, M., Prasad, R., Pathania, V., Gill, B.S., Singh, D., Chand, G., Singh, B., Singh, R.D., and Ahuja, P.S. (2015) 'Cropecology and nutritional variability influence growth and secondary metabolites of Stevia rebaudiana Bertoni', J. Plant Physiol, 67, pp. 1-16. doi: 10.1186/s12870-015-0457$\mathrm{x}$.

Parris, C.A., Shock, C.C., and Qian, M. (2016) 'Dry leaf and steviol glycoside productivity of Stevia rebaudiana in the western United States', HortScience, 51, pp. 1220-1227.

Rafiei, F., Nourmohammadi, G., Chokan, R., Kashani, A., Haidari, H., and Abad, S. (2013) 'Investigation of superabsorbent polymer usage on maize under water stress', Global Journal of Medicinal Plant Research, 1 (1), pp. 82-87. ISSN 20740883.

Rashad, M., Kenawy, E., Hosny, A., Hafez, M., and Elbana, M. (2020) 'An environmental friendly superabsorbent composite based on rice husk as soil amendment to improve plant growth and water productivity under deficit irrigation conditions', Journal of Plant Nutrition, pp. 1-13. doi.org/10.1080/01904167. 2020. 1849293.

Santos, M.G., Ribeiro, R.V., Machado, E.C., and Pimentel, C. (2009) 'Photosynthetic parameters and leaf water potential of five common bean genotypes under mild water deficit', Biologia Plantarum, 53 (2), pp. 229-236.

Sarvaš, M., and Pavlenda, P. (2007) 'Effect of hydrogel application on survival and growth of pine seedlings in reclamations', Journal of Forest Science, 53 (5), pp. 204209.

Shangguan, Z., Shao, M., and Dyckmans, J. (1999) 'Interaction of osmotic adjustment and photosynthesis in winter wheat under soil drought', J. Plant Physiol, 154, pp. 753-758.

Souch, C.A., and William, S. (1998) 'Growth, productivity and water use in three hybrid poplar clones', Tree Physiology, 18 (12), pp.

829-835. doi.org/10.1093/treephys/18.12.829.

Tavarini, S., Passeraa, B., and Angelini, L.G. (2015) 'Crop and steviol glycoside improvement in stevia by breeding', Food Chemistry, doi:10.1039/9781788010559FP001.

Weising, K., Nybom, H., Wolff, K., and Meyer, W. (1995) 'DNA fingerprinting in plants and fungi', (CRC Press, Boca Raton, FL). cabdirect.org/cabdirect/abstract/1995161 1008.

Yem, E.W., and Willis, A.J. (1954) 'The estimation of carbohydrates in plant extracts by anthrone', Biochem. J, 57, pp. 769-773.

Yousefian, M., Jafari, M., Tavili, A., Arzani, H., and Jafarian, Z. (2018) 'The effects of superabsorbent polymer on Atriplex lentiformis growth and soil characteristics under drought stress: Case study Desert Research Station, Semnan', Iran. Journal of Rangeland Science, 8, pp. 65-76. 